\title{
FILM REVIEW
}

Kunle Afolayan, dir. Mokalik. 2019. 100 min. Yoruba. Nigeria. Golden Effects Pictures. No Price Reported.

Kunle Afolayan's Mokalik — a Yoruba transliteration of the word "mechanic"is an original contribution that compels the attention of prospective viewers, scholars, and other stakeholders because of the sophistication deployed in its creation.

As the title suggests, the film is about the shades of experience in a mechanic complex, where life is lived and memories are made. But rather than being exclusively about mechanics and other technical tradesmen, Mokalik unfolds more as a narrative about the whole of the Nigerian postcolonial state in the twenty-first century. It forges a narrative link between the occupants of the lower rung of the social ladder in Lagos and members of the upper-middle class who live on Lagos Island. The decision by Mr. Ogidan (Femi Adebayo) to send his high school-age son Ponmile (Tooni Afolayan) generally referred to in the film as Ponle-to intern for a day at the mechanic complex not far from the Lagos Airport sets up the social class interface. The narrative thus builds up and progresses as a one-day affair, much like James Joyce's Ulysses.

The nuanced and animated characterization in Mokalik is facilitated mostly by nicknaming, as such names pinpoint the contradictions of the personalities they reference. Names such as Adelabu and Obama remind one of both local and international politics. But more importantly, the assembly of the technicians at Iya Simi Food Canteen for their breakfast and lunch offers insights into how such a location within the workshop serves as a platform for public sphere debates among the mechanics on several issues of local and international import. The nickname NEPA for the automobile electrician is a nimble critique of the substandard and dystopian condition of the Nigerian electric power situation. It reminds the viewer of the original acronym of the National Electric Power Authority (NEPA), the power generation agency notorious for intermittent supply. Afolayan's nuanced critique is facilitated by a dialogue on the role of an alternator in a car, as explained by NEPA to Ponle. The boy quickly connects this role to the value of the UPS generator in their home, which automatically makes it possible for

(c) The Author(s), 2021. Published by Cambridge University Press on behalf of the African Studies Association. 
their television set to continue working despite electrical power outages. It is in this way that Afolayan makes a deft commentary on how individuals have in their various home and business lives assumed the responsibilities of failed public institutions such as the NEPA. The NEPA has since been replaced by other power agencies, which, however, have not transcended the substandard performance evocative of their predecessor.

The import of the meeting between Ponle and Simi, a Nigerian female singer of international repute who plays herself in the film, underscores the innovative intentions of Afolayan to push generic boundaries in Nollywood by reconfiguring the subgenre of fictional autobiography. As revealed on a social media platform some time ago, Afolayan actually once sent his son to train at a mechanic workshop during a school vacation. That experience informed the storyline of Mokalik; but the story becomes even more intriguing because of the way it interfaces with the autobiography of Simi, who grew up in Ojuelegba, an overcrowded suburban slum of Lagos. Afolayan initiates a conversation between otherwise parallel social lines that now meet to confer and learn from each other. Simi's Ojuelegba background depicts her as representative of the deprived and the dispossessed, while Ponle, coming from the Island, symbolizes the privileged youth. The flirtation between them serves as a device for getting to the heart of the matter: much as higher learning is desirable as a strategy to enhance living, one should not ignore vocational and creative aptitudes. In the case of Simi, her musical ability sidetracks her motivation for further studies after completing her diploma programme in a polytechnic. By regaling viewers with some of her hits, including "Jamb Question," while working in her mother's kitchen at the mechanic workshop, the character Simi blurs the boundary between the fictive and the autobiographical.

Ponle is fascinated by her talent and urges her to pursue her desire to make a career of music. In a similar vein, much as Ponle keeps his eyes on his high school education, he is further persuaded through the advice of Simi that his sleight of hand is likely to pay off better than a purely academic pursuit. Their conversation reveals other dimensions to Simi's real-life success, while punctuating Ponle's potential, should he nurture his vocational aptitude as he pursues formal education, which is the ultimate point of the film. Invariably, Afolayan's stardom may be regarded as logical, considering his privileged background as the son of an iconic Nigerian theatre performer and film maker. Still, Simi's deprived background has not prevented her rise to stardom through her musical aptitude. It is in this sense that Afolayan accomplishes a sophisticated and stunning reconfiguration of the fictional autobiography in Nollywood. But in addition to the autobiographical insights, Mokalik reveals much more about the quotidian routine of life at the mechanic complex as a domain of passion, rumors, conspiracy theories, contradictions, violence, order, discipline, and care, in addition to being a space of technical knowledge acquisition and service.

As the film winds up with the return of Mr. Ogidan to pick up his son, many lessons are learned. Perhaps the most memorable of the last moments 
is Ponle's ability within the single day to learn from Kamoru the interval in the arrival of airlines at the Lagos Airport. Yet, from Simi to Erukutu and Toafeek, the apprentice painter Kamoru is referred to as the idle one for mastering the airlines' arrival schedules, which leaves the viewer with the question: Is Kamoru in the right place for learning? Certainly, Kamoru would have loved to be in the university, mastering the engineering of aeronautics and flight instead of studying the arrival of airplanes at an automobile workshop. Therefore, Kamoru's apparently incongruous mastery of the airlines' schedule rather than mechanic skills is definitive of aspiration toward the ideal, in the same way that the film's opening broadcast about a traffic-free Lagos is nuanced creative advocacy and transformational desire for an improved transport system in the city.

Mokalik represents a novel approach to the use of autobiographical material in fictional films. This generic conflation challenges film scholars, and Nollywood scholars in particular, to view the postcolonial social imaginary in a new light. Afolayan's creative approach to storytelling has produced a film with many levels of meaning, one that entertains viewers while addressing pertinent social issues. 